$7-31-2020$

\title{
Malay minorities in The Tenasserim coast
}

\author{
Ma Tin Cho Mar \\ Department of South East Asian Studies, Faculty of Arts and Social Sciences, University of Malaya, Kuala \\ Lumpur, Malaysia, matinchomar@gmail.com \\ Pham Huong Trang \\ International School, Vietnam National University, Hanoi, Vietnam, trangpham.isvnu@gmail.com
}

Follow this and additional works at: https://scholarhub.ui.ac.id/ajce

Part of the Polynesian Studies Commons

\section{Recommended Citation}

Mar, Ma Tin Cho and Trang, Pham Huong (2020). Malay minorities in The Tenasserim coast. ASEAN Journal of Community Engagement, 4(1).

Available at: https://doi.org/10.7454/ajce.v4i1.1069

Creative Commons License

(c) (i) (2)

This work is licensed under a Creative Commons Attribution-Share Alike 4.0 License.

This Review Article is brought to you for free and open access by the Universitas Indonesia at ASEAN Journal of Community Engagement. It has been accepted for inclusion in ASEAN Journal of Community Engagement. 


\title{
Malay minorities in The Tenasserim coast
}

\author{
Ma Tin Cho Mara*, Pham Huong Trangb \\ ${ }^{a}$ Department of South East Asian Studies, Faculty of Arts and Social Sciences, University of Malaya, Kuala \\ Lumpur, Malaysia
}

bInternational School, Vietnam National University, Hanoi, Vietnam

Received: December 29th, 2019 || Revised: January 30th 2020|| Accepted: July 29th 2020

\begin{abstract}
This paper discusses the Malay Minorities of the Malay Minorities in the Tenasserim Coast. And Tanintharyi Division is an administrative region of Myanmar at present. When we look closely at some of the interesting historical facts, we see that this region is "Tanao Si" in Thai, or Tanah Sari in Malay. This region belonged to Tanah Melayu, or Malay Peninsula, which was part of the Sultanate of Kedah. It was occupied first by the Ayutthaya Kingdom and later by Burma. Moken people of the Austronesian-speaking tribes who live on the coast and on the islands of the Andaman Sea up through the Mergui Archipelago of Myanmar have rationally attracted the attention of researchers. The group includes the Mokens themselves, the Moklen (Moklem), the Orang Sireh (Betel-leaf people) and the Orang Lanta. The Orang Lanta are a hybridized group formed when the people of Malay settled in the Lanta Islands, where the proto-Malay Orang Sireh had lived. The Burmese call the Mokens "selung," "salone," or "chalome." For this study, secondary data on the relevant history was collected and two complementary approaches were used as the research methodology to identify, analyze, and understand different patterns of knowledgesharing within complex social systems. Finally, the paper discusses the significance impact of human migration in Southeast Asia.
\end{abstract}

Keywords: Tenasserim coast; Moken; Salone; Pashu; Malay; minorities; human migration.

\section{Introduction}

In the opinion of Ibrahim (2013) Malays are increasingly challenged to uphold and sustain their traditional values. The history and civilization they built together and shared must be maintained, for the sake of new generations and the generations to come. Despite the modern multicultural world giving little importance to indigeneity and cultural identity, the importance of exploring and reconstructing Malay roots and its DNA connections, its people's own historical narrative of its land and its seas, are always challenging. "Malay communities" is a broader term encompassing both the diaspora and its minorities. "Diaspora" is sometimes used with a political connotation; likewise, "minority" is a word that is discouraged in order to avoid the feeling of majoritarianism. "Malay diasporas" are Malays who have gone to other lands to earn a 
Ma Tin Cho Mar, Pham Huong Trang | ASEAN Journal of Community Engagement | Volume 4, Number 1, 2020

living/study/migrate/ or are even banished to the US, Sri Lanka, etc. "Malay minorities" are Malays are second-class citizen in their own motherland, as, for example, in Tenasserim in southern Myanmar, in Cambodia, etc. Throughout the Austronesian world, Malays are not diasporas. Not even in New Zealand and Australia are they diasporas. They may be minorities, but the Whites there are diasporas. All Malays in the Pacific are natives, being the first human population. The islands are their homeland.

In the earliest of times, the Malay-Polynesians, from 14,000-12,0000 BC, were the leading indigenous inhabitants of the earth, spreading over the globe. Malays were the leading explorers, settlers, agriculturalists, scientists, and navigators, second to none in those exploits. The Malays spread across some four-fifths of the globe, speaking more than 1200 variations of the same language structure and roots. Despite the arrival of others onto Malay shores and lands, the shared Malay values continue to shine as steadily as the morning sun (Ibrahim, 2013).

Many of the present generation scholars and historians in Asia have insisted that the earliest major civilizations of the world were Indian and Chinese. The standard world history may even omit Malays from its mainstream reference. However, more recently, honest Western prehistorians, marine archaeologists, linguists and anthropologists have discovered that Nusantara was once the center of world civilization, and that others, like the Sumerians, Mohenjo-Daro, and the Chinese were passive receivers of the Sunda Civilization. According to Ghazali and Ramli (2013), Malays lost ground in rediscovering and reconstructing Malay civilizational heritage until the moment they were colonized by foreign powers during the $15^{\text {th }}-17$ th centuries.

Lynn (2010) asserted that the Tenasserim Coast is the most southernmost part of the State of Myanmar. Located on the western coast, adjacent to the narrower Isthmus of Kra, connecting South East Asia with the Malay Peninsula and the wider Southeast Asia. In the history, Mergui was the most important town and famous as the major western port on this coast of the Thai state of Ayutthaya until its fall to the Burmese in 1760. However, this area has become unknown to the world today as it is largely located under the control of rebels later few centuries ago. The Tanintharyi Division is a recent administrative region of Myanmar. This region is called "Tanao Si" in Thai and "Tanah Sari" in Malay. Historically, this region belonged to Tanah Melayu, or Malay Peninsula, which was part of the Sultanate of Kedah (Stier, 1927) and initially invaded by the Ayutthaya Kingdom and later by Myanmar (Wilkinson, 1923). 
Ma Tin Cho Mar, Pham Huong Trang | ASEAN Journal of Community Engagement | Volume 4, Number 1, 2020

The people of Malaysia, in the Myanmar Archipelago of Myanmar and the island of southeast Thailand are known as moken, or similar moklen (Salaone). Two other subgroups are Orang Laut, the most prominent group of the Sulu Archipelly of the Philippines, North of Borneo and Sulawesi and the Islands of eastern Indonesia, in the Riau-Lingga Archipelago, the Western of Indonesia, and Southern Johore in Malaysia and The Bajau Laut. In Sabah, East Malaysia, the Bajau is also the largest Muslim tribe recognized as Sea Gypsies, or Island Nomads. In Myanmar (also called Burmas Pashu), the Malaysians in Singapore, Brunei, the Philippines and Indonesia are almost the same as the Malaysians in others. Within the Malayic Sea Tribe lects, this paper shows how extent of the Tenasserim Hills and their subranges in following figure.

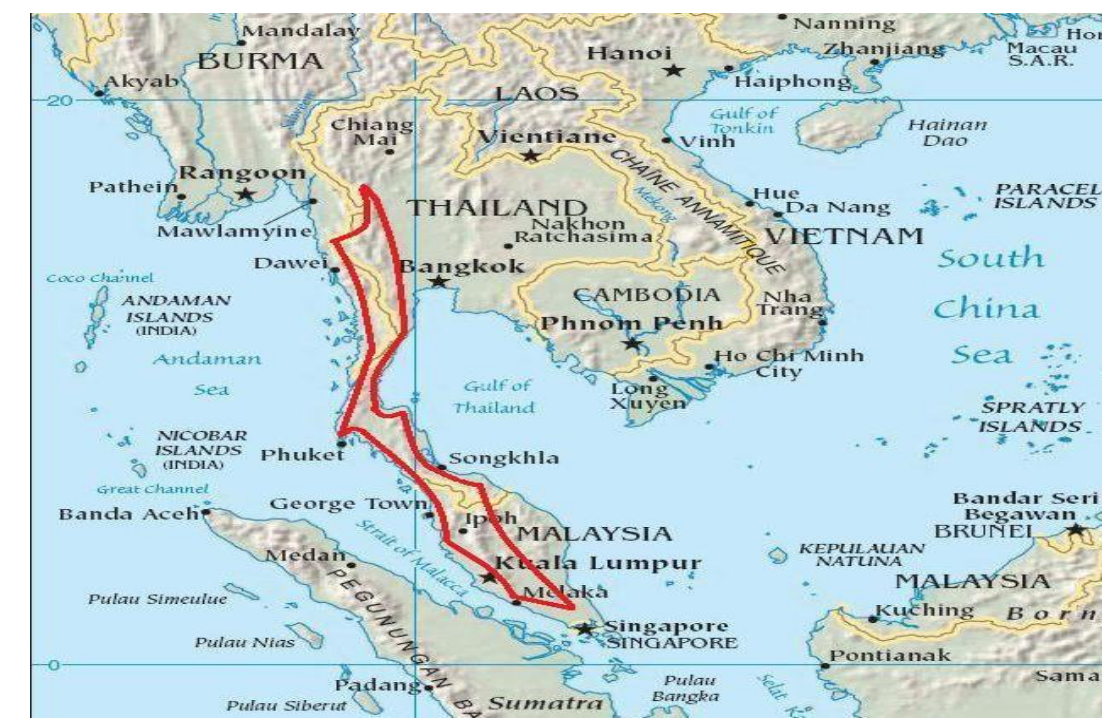

Fg. 1 Extent of the Tenasserim Hills and their subranges

Source: https://www.cia.gov/library/publications/the-world-factbook/index.html - Southeast Asia Map

\section{Methods}

To discuss the significance attached to the aspects of human migration in Southeast Asia with relevant methods used for this study based on migration theory.

According to Bernardini (2005), historically ancient human populations are inherently inaccurate due to their unsettled nature. For instance, to interpreting identity issue from material culture should be responsively needed to identify based on the nature of ethnic group although there was some inadequacy to identifying their groups and movements.

Based on Lucassen, Lucassen, and Manning (2010), researchers in three disciplines such as anthropology, sociology, and history have dominated human migration studies. If 
Ma Tin Cho Mar, Pham Huong Trang | ASEAN Journal of Community Engagement | Volume 4, Number 1, 2020

we investigated anthropological approaches, there are many types of subdisciplines especially archaeology, ethnology, cultural anthropology. Such approaches have been transformed to theoretical frameworks focused on climateology, genetically engineering and cultural structures such as marriage and the child. Contemporary migration patterns including economic, demographic, social, and political oriented theoretical model are used to analyze human migration based on the sociological approach. Key questions for this approach are to find out who is migrating, why, when, where and how they move in the research context.

According to Din (2011) there is still no proof of the precense of Austronesian speakers in other parts of the world. As a result, all the migration theories were deficient and the Malaysians were the first to create prolonged political and geopolitical entities (like Malay Land). We also relied on the Malay Concordance Project to understand the historical use of words such as "Tanah Melayu" and "Nusantarian motherland" (http://mcp.anu.edu.au/cgi-bin/tapis.pl. Retrieved 8 April 2012) the most useful source of Malay studies in general. This paper also refers to the early 19th century European accounts by Marsden (1811 \& 1812), Raffles (1830 \& 1817), and Crawfurd (1819, 1852).

\section{Result and Discussion}

\subsection{Waves of prehistoric migration}

One of the questions commonly asked when discussing the history of a settlement, the Austronesians created the final wave of the final great human exodus into the Island South East Asia (ISEA) region including Peninsular Malaysia. Hence, Taiwan or ISEA is seen as their homeland based on genetic studies (Chambers, 2006; Chambers \& Edinur, 2015; Simanjuntak, Pojoh, \& Hisyam, 2006). Crowed marine traffic through the straits of Malacca on the west of Peninsular Malaysia made this region to be the major strategic hub for international trading activities among India, China and other countries in South East Asia, reaching to coastal Africa, Arabia and Europe (Belle, 2014). The later Malay Empires from $6^{\text {th }}-17^{\text {th }}$ century regulated the rapid growth of trading activities in this region of South east Asia (Baker, 2020; Norhalifah, Syaza, Chambers, \& Edinur, 2016) which preceded increased demand for forest products mainly supplied by Orang Asli (Andaya, 2002). In other words, it shows historical evidence of trading interactions between Malay not only with India, Arabs and China but also with Orang Asli. 
Ma Tin Cho Mar, Pham Huong Trang | ASEAN Journal of Community Engagement | Volume 4, Number 1, 2020

The Malays were the first to settle on the Tenasserim littoral, at least as far as the islands and the mainland town of Bokpyin (Boutry, 2014). Since the late sixteen century, coastal fishermen on the littoral reproduced the villages in Kawthaung, and in the village of Pulotonton which are similar to the economic structures of the villages in Malay Peninsula (Light \& Gold, 2000) until today. In the islands they specialized in piracy, although to a lesser extent than by islands in the Malacca Straits. The Mergui Archipelago pirates were more likely at the extreme edge of the slave raiding that was perpetrated throughout the Malay Archipelago. Andaya (2002) and Andaya and Andaya (2016) noted a presence of "communities of able seafarers" in western Nusantara since three thousand years ago. Figure 2 below shows the dominance role of Sea Tribes in the 17th century in regulating certain ports to collect important sea products for trading.

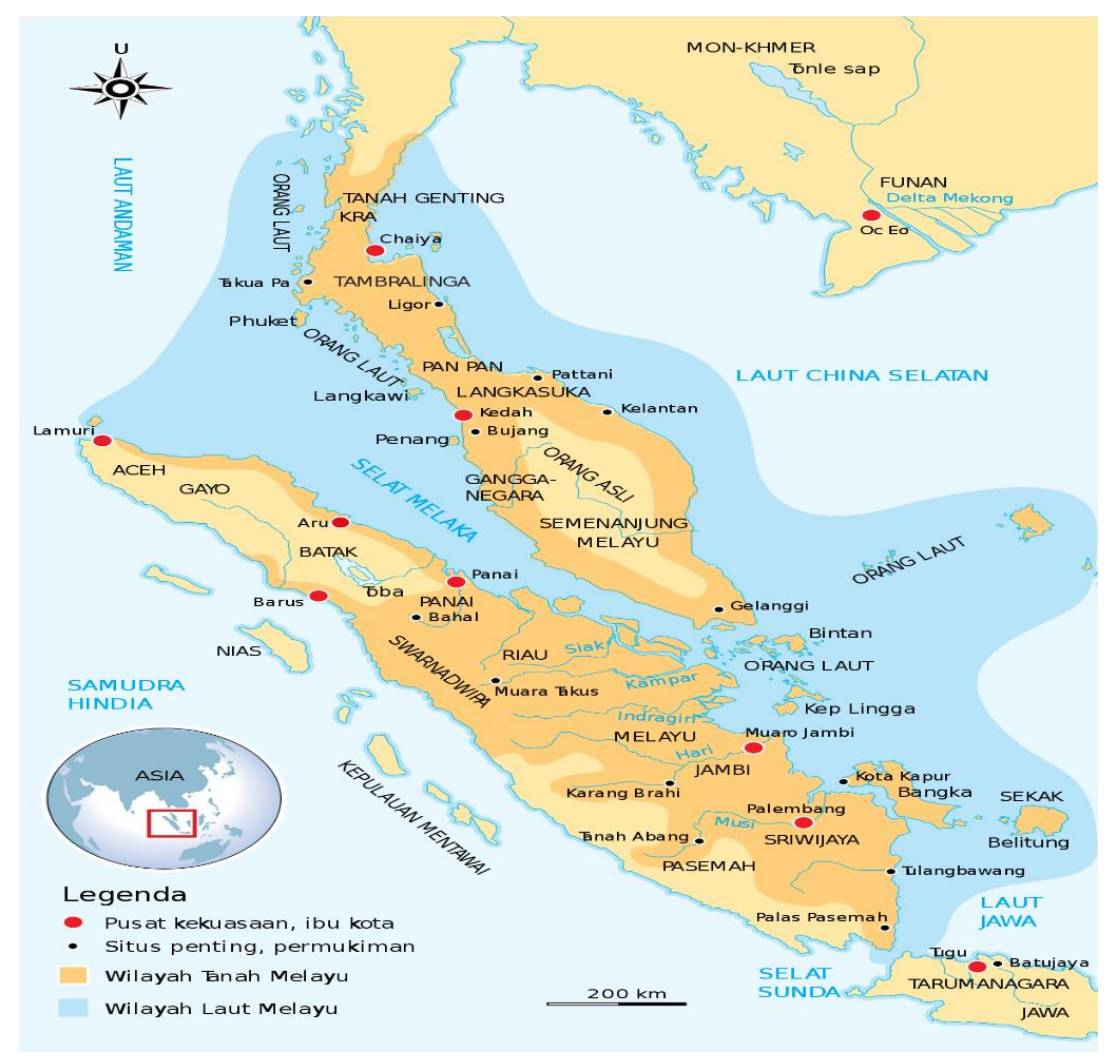

Fg. 2 Malay Kingdoms

Source: Maps of the History of Srivijaya

On the other hand, the Mon people were the first to set foot in the region of Indochina. They established some among the first settlements such as the Dvaravati in Central Thailand, Hariphunchai in northern Thailand, and the Thaton Kingdom at Tenasserim. The Sri Gotapura established themselves in central Laos, now modern 
Ma Tin Cho Mar, Pham Huong Trang | ASEAN Journal of Community Engagement | Volume 4, Number 1, 2020

Sikhottabong, Vientiane Territory, and northeast Thailand. In comparison to their Hindu social classes, such as the Khmer and Cham people, they were among the first missionaries from Theravada from Sri Lanka to arrive.. The Pallava alphabet was adopted by the Mon and their first script found from approximately $550 \mathrm{AD}$ in a cave in modern Saraburi. While no part of Thaton 's Kingdom was discovered, it was widely reported in the chronicles of Bamarand Lanna. Around 800 AD, in modern Lamphun according to Câmadeviva AND Northern Thai Chronicles, the legendary Quên Camedevi from the Chaos Phraya River Valey became the first queen of Hariphunchai kingdom.

From 1000 AD onwards, the Mon suffered invasion wars from the Tai people invading from the north and Khmer from the east. Many have been killed in conflicts, brought into captivity or brought in new cultures. The Mon of Dvaravati moved to the Lavo kingdom and they virtually disappeared from the Chao Phraya Valley, according to (Ibrahim, 2013). The Nyah Kur people of Isan are descendants of the Dvaravati Mon people. Earlier, Dvaravati Myanmar and Siam were undoubtedly Malays.

Many researchers are currently interested in Austro-Asiatic and Austronesian groups. The term "Austronesian", or "Austronesian-speaking peoples" are used to describe people speaking this language family (Baldick, 2013). This language family consists of Formosan (Taiwan), and Malayo-Polynesian which have many sub-families such as (Borneo groups, Chamic groups, Champa groups, Central Luzon groups, Igorot, Lumad (Mindanao), Malagasy (Madagascar), Melanesians (Melannesia), Micronesians (Micronesia), Moken (Burma, Thailand), Moro (Bangsamoro), Northern Luzon lowlanders, Polynesians (Polynesia), Sunda-Sulawesi groups and Visayans and neighboring islands (Van Driem, 2007). Nevertheless, there is no evidence of any biologically or culturally shared ancestry between all Austronesian-speaking groups , especially where there is a considerable interaction between the two groups. Charles Higham, a New Zealand archaeologist, has focused on the so-called Austric Hypothesis. Austroasian refugees from Southeast Asia descend from the Munda people (Igboanusi, 2017; Riccio et al., 2011) and primary division of the family in Central and Eastern India is between the Munda languages (Brown \& Ogilvie, 2010).

The Hariphunchai was Mon Kingdom, which was repeatedly conquered by the Thai people of northern Thailand. Mon was adopted and was ruled by Bamar in 1057, when King Anawrahta of the Pagan Kingdom conquered thaton 's kingdom. In Lower Myanmar, 
Ma Tin Cho Mar, Pham Huong Trang | ASEAN Journal of Community Engagement | Volume 4, Number 1, 2020

the Mons were dominant. Once Mangrai, the ruler of north Thai, captured the Hariphunchai in 1230, the Mon religion was integrated into Lana society.

The mon was unified with the victory over the invasions of the barma Ava kingdom by King Rajathiraj (1383-1422). The Mon was peaceful and prosperous during the time of Shin Sawbu (1453-1472) and Dhammazedi (1472-1492). The Barma regained power in Taungoo at the beginning of the 16th century. Up to the death of the Taungo King Tabinshwehti, then the Mons liberated the rule of Bamar, defeated in 1551 by the Bayinnaung King. During the following 200 years they also immigrated to Ayutthaya, Thailand, where their relatives were Bamar, Thai and Rakhine. The Mon from Lower Myanmar had suffered from war fronts. Later King Naresuan's chief advisor was a priest.

The Mons were again under the Bamar when the King Anaukpetlun was reunited in 1616. Most of them were granted residing in Western Thailand, holding important posts in Thai military and political affairs, following the Mon rebellion in this year. (Van Roy, 2018). The Chankri dynasty in Thailand was later created, with a special regiment set up to serve the Thais king by the Mons.

In 1740, with the assistance of the Gwe Shan, the successful uprising of the Mons enabled them to remember their strength in Bago. The King of Bago was a Bamar monk with royal Taungoo row. The Mon then established its independent kingdom in 17 years with the aid of the French until Alaungpaya was invaded in 1757 and backed by the British army. Thousands of Mon, among them priests, pregnant women, and babies, were murdered, and massacred. More than 3000 priests were massacred only in the capital of Bamar alone. This led to a migration surge into Thailand and Mon Lana. The following illustration shows how ethnic Malaysians spread particularly in Tenasserim Costal in South-East Asia. 
Ma Tin Cho Mar, Pham Huong Trang | ASEAN Journal of Community Engagement | Volume 4, Number 1, 2020

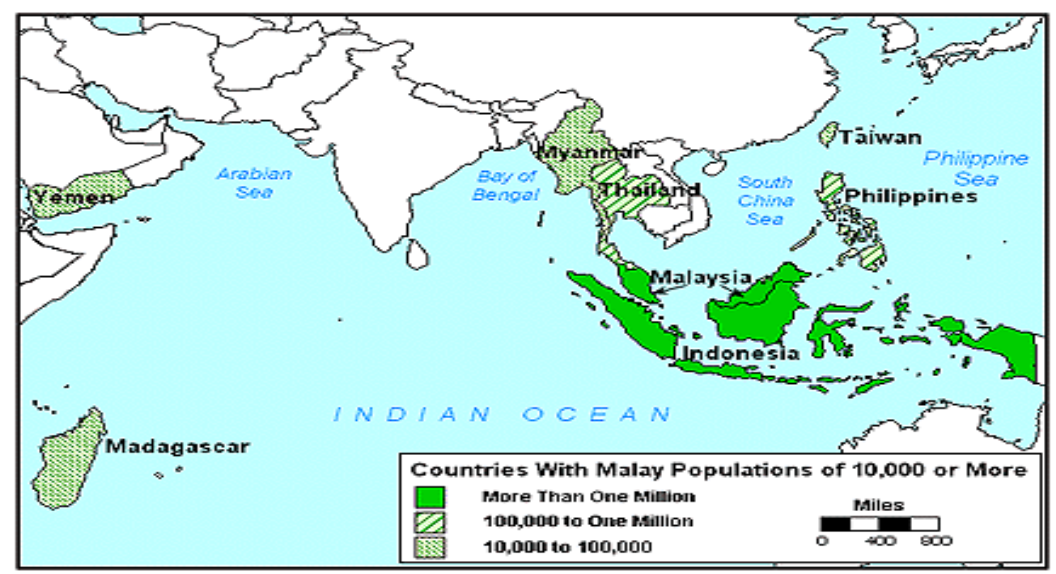

Fg. 3 "Malay minorities in the Tenasserim coast"

Source: Bethany World Prayer Center. https://joshuaproject.net/people_groups/13437/JA

A Malay scholar, Abdullah Mohamed or Nakula (1991) wrote the Malay history precisely. He can read Sanskrit \& Arabic, his impactful historical narratives concerned Funan and the Grand Kaundinya Tradition in Cambodia about Huntian, the founder of Funan. That founder of Funan had a dream that directed him to collect a javelin or bowand-arrow at a temple and to continue traveling on a mission to Vietnam. He sailed north, where he was confronted by a warrior princess named Soma. Soma apparently had origins in Nagaland, on the slopes of the. Fast-forward, he came upon the lady warrior and her troops. He fired an arrow into her ship \& defeated them. Eventually he married her. She was found half naked (primitive) so he covered her in more appropriate dress fit for a Queen, thus introduced first court ritual that symbolized the Malay nobility in Indochina.

The Funanese were great metallurgists, traders, and craftsmen (Embongak, Jusohb, Husseinc, \& Mohammadd, 2016). The empire grew in prosperity, and was considered the Rome of the East, outflanking the Chinese. Education was promoted, gold was used for currency and ornaments. Indeed, the Indians called this region "Suvarnabhumi." Scholars have speculated that the language of the Funanese was Mon-Khmer. The Mon must be from Naga, in Myanmar, while the Khmer was Cambodian. However, if the nobility had been Kelantanese all along he may have brought his well-developed Kelantanese there, too. As such, he must have been speaking cosmopolitan languages like Kelantanese, Mons, Chams \& Khmer.

Funan grew in prosperity from the 1 st through $6^{\text {th }}$ centuries $A D$, conquering 10 territories from Myanmar to Vietnam and north Malaya, but was ultimately defeated by 
Ma Tin Cho Mar, Pham Huong Trang | ASEAN Journal of Community Engagement | Volume 4, Number 1, 2020

Chenla, later Angkor. Chenla's army were relatives of Funan (Coedes) so another Malay kingdom grew on the Mekong River, after which Angkor took over. The Angkor term for empire was Kambujadesa. The Pyus of Myanmar was Ramannadesa. In short, Mons (3 $3^{\text {rd }}$ $9^{\text {th }}$ century AD). Another big Malay kingdom on the Menam Chao Phraya was Dvaravati, which fell to invading Thais in the 13th Century.

\subsection{The historical genetic evidence}

One prehistorian,(Renfrew, 1990) believes that pre-colonial Southeast Asia was not known in Europe until 1500 AD. He pointed to the emergence of Southeast Asia from the colonial yoke, 50-100 years ago. The moment Asians attained independence, all textbook materials were couched in their histories and with Asians as native participants within their margins of reference. The 15th-17th centuries were the European Age of Discovery. Western scholars writing regarding Malay ethnicity skewed and narrow. Asians were portrayed as half naked, indolent, and devoid of civility and civilization. One Malay scholar, Syed Hussein Alatas, in his studies of the post-colonial experience in Java, Sumatra and Philippines, wrote "The Myth of the Lazy Native (1970)" was hot reading for many intellectuals. A dissertation of Robert in 2010 also documented how traditional Urak Lawoi' lifeways and language are changing to outside influences of Western and Thai (Anderbeck, 2012).

The West was keen to find the Spice Islands, as well as gold and other precious materials. These were the inspirations that sent Columbus, Drake, Cook, Tasman, Alfonso, Raffles, and Light to Asian shores. Then Asians find how these names became heroes and "discoverers" of Asian native lands, though we had been here 50,000 years before them (Ibrahim, 2013). By time Wan Teh (2016) comprehended to unlock one of Malays prehistoric archives, we were already in the Sunda Civilization. The Sunda Civilization, its knowledge, its influence, and its global maritime reach, may have opened Malaysia's sense of history, its voyages, crafts, and discoveries into a meaningful pattern, making sense of our present lives, enough and complete.

Dr. Stephen Oppenheimer was a medical scientist in Malaya but undertook many studies into the indigenous Orang Asli ethnic subgroups. Over time, he gathered oral and written evidence of the region. He studied flood effects of the Great Flood of Noah, its probable cause being volcanic eruptions and overall catastrophe in the Nusantara and Sunda Platform, especially see at Figure 4. 


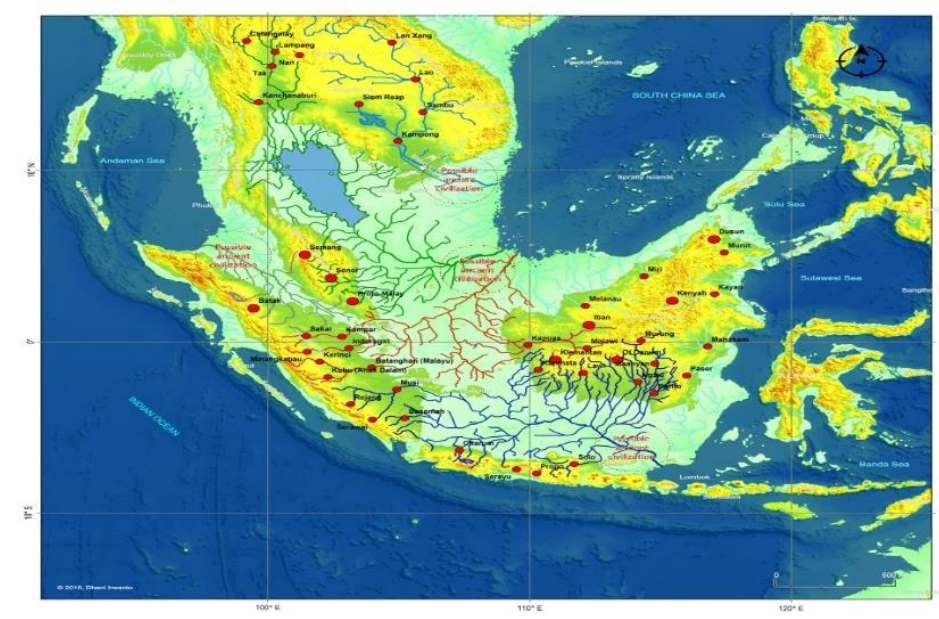

Fg. 4 Sunda Platform with intersecting rivers Source: https://www.bing.com/images/searchview

On the other hand, the Mergui Archipelago lies off along the south coast of Tenasserim, follows a north-south axis by reaching to the north to the littoral town of Dawei and to the south as far as Phuket in Thailand (Boutry, 2014). Since the 17th century, the Mon, a population of Sea Nomads of Austronesian origin have lived on its islands. In fact, the Mergui Archipelago is part of the wider Malay Peninsula, including provinces in the south of Thailand and northern Malaysia. Even geographically, the Tenasserim marks the fusion between Myanmar and Malaysia, according to the ecological similarities between the two countries (White, 1922).

As he wrote, Myanmar is the country of the peacock, while in the Tenasserim, as in Malaysia, the pheasant dominates (White, 1922, p. 27-28). Other animals common in Malaysia, such as the pangolin and the mousedeer, are found in this region. As for the flora, the resemblances to Malaysia are significant, with the kanyan, for example, supplanting the teak, and the zalacca (Zalacca rumphii), is indispensable for the construction of the kabang, the boat of the Moken Sea Nomads. Besides the Moken, the Malays were in the majority of those frequenting the islands of the Mergui Archipelago. Even though the border was negotiated between Siam and the British Empire in the nineteenth century, the entire region remained a transnational borderland with limits situated inside the national territories. Those designated cultural and geographic elements more than administrative ones. Consequently, a cultural border existed between paddy states and thalassocracies (maritime realms), rice culture and commerce, 
Ma Tin Cho Mar, Pham Huong Trang | ASEAN Journal of Community Engagement | Volume 4, Number 1, 2020

continental and insular Southeast Asia. Tenasserim is the de facto border separating central and Lower Myanmar from the Malay Peninsula, including the south of Moulmein and the Mergui Archipelago, regardless of the official national border.

Since the beginning of the 1980s, the Mergui Archipelago has become a shelter for numerous Burmese, mostly coming from Lower Myanmar, and thus the theater of an appropriation process of the marine and insular environment, involving both the Burmese and the Moken. Consequently, this study highlighted that the present-day administrative border, marked by Kawthaung and Ranong immigration checkpoints, is as much the result of a social construction as a national one. The modern national border between southern Myanmar and Thailand, derives primarily from an action of socialization pushing back the cultural "frontier," in the sense promoted by the American historian, Frederick Jackson Turner (1893), between the implicitly wild (non-Burmese) and the civilized (Burmese) territories. For the past 20 years, the Mergui Archipelago has been thus a pioneer borderline whose progress can be attributed to a handful of typical Burmese. Both the Moken and the Burmese undertook the creation of a new space to face the political, social, and economic changes, based on a system of structural interactions between the two populations. As a matter of fact, these pioneers, by making certain social and cultural "sacrifices" to withstand the integration into the new style of Burmese geopolitics projected through the military dictatorship, paradoxically helped the nation building of its territory.

Many of the original investigators initially identified Moken in Malaysia and Indonesia as primitive non-muslims, since in Johore, Batang Island of Indonesia, Sarawak (Eastern Malaysia) and Singapore people are mainly Muslims, and Myanmar / Burmese Pashus (Bajou). Particularly many of the Burmese Moken married indigenous Muslim, Arabian and Indian traders in the Western Malay Peninsula. Such Muslims have both Burmese and Malaysian citizenship and use this language in Malay.

In Bokpyin Township and the villages surrounding it, as well as on several large islands in Bay of Bengal in Taninthayi Division, Myeik, a district in south Myanmar, numerous people have been living through fishing, perla-diving, farming and diverse trades for a long time. They are Malay, speak Malay and some of their elderly people can read Jawi, Malay in Arabic, different from the standard Malay in Romanesque. Alongside the most northern part of the Sea Nomads, the Moken call themselves Manut Tan'au, People of the Sea, live in boats by fishing and hunting seafoods on islands around the 
Ma Tin Cho Mar, Pham Huong Trang | ASEAN Journal of Community Engagement | Volume 4, Number 1, 2020

Mergui Archipelago in the Andaman Sea. Moreover, their cultivation knowledge is also excellent with more than hundreds of species of culturally important plants used as food, medicine, construction materials and religious utensils (Hinshiranan, 1997).

Throughout culture, all belonging to the Tanintharyi, the Tanintharyi, the Mon State and Southern Kayin Region. After Bagan 's defeat, in 1287, and then King Bayinnaung of the Toungoo Dynasty, the Siamese kingdom of Sukhothai was overthrown in all of Siam. By 1587 Ayutthaya regained independence and in 1593 regained Taninthary's southern half, the entire peninsula in 1599 and Dawei's the upperside, but not the rest. As a result, Tenasserim south of Dawei (called Tayoy) remained under Siamese control, while the port of Myeik (Mergui) became the key hub for trade between Siamese and European people. (Charney, 2009; Harvey, 2000).

Burma and Siam were engaged in several wars to seize power on the coast from the middle of the 18th to early 19th centuries and Kengtung and Lan Na on the north front for their benefit. The Siamese's attempts to retake Tanintharyi (1787 and 1792) were also unsuccessful. Also, Ibrahim (2017) stated, "The Andaman Sea, off the Tenasserim Coast, was the subject of keen scrutiny from Burma's regime during the 1990s, due to offshore petroleum discoveries by multinational corporations, including Unocal, Petronas and others.". Based on reports from the late 1990s, the Sea Gypsies were forced to relocate to mainland sites by Burma's military regime. Although the Sea Gypies have lived on coastal provinces in Thailand's Andaman for ages but without registered official ownership of their land due to their lack of knowledge on legal protocol, they become the target or land grabs (na Thalang, 2017).

\subsection{The linguistically evidence}

In a cave at Saraburi, about $550 \mathrm{AD}$, the script of Mon and the alphabet of Pallava adopted by Mon was found. Then in 1057 during the Thaton Kingdom defeated the King Anawraht of Pagan Kingdom, the mon culture and the script were assimilated and came under Bamar rule by the Burmese and mons. In Lower Burma, the Mon remained the majority. In 1230, Mangrai- Northern Thai leader introduced Mon culture and script into the culture of Lanna as Haifunchai was conquered. (Baker, 2014; Haspelmath \& Tadmor, 2009). 
Ma Tin Cho Mar, Pham Huong Trang | ASEAN Journal of Community Engagement | Volume 4, Number 1, 2020

The Burmans invaded Mon territory and adopted Mon script for Burmese during the time of Anawrahta's reign. There is still no consensus among specialists regarding the ethno-linguistic nature of peple. Hence, most specialists agreed on hypotheses that Funanese were mostly Mon-Khmer, or Austronesian, or they themselve created a multiethnic society. According to Omar (1996), in all South East Asian native languages include Austronesian, Pupuan, Tai-Kadai, Austro-Asian and Tibeto-Burma, the most common in South East Asian islands, the Malaysian Peninsula, Hainan and Taiwanese Hill (Formosa) and the Austronesian one.. The Papuan stock is only in New Guinea. The Austro-Asiatic family of languages consist of the Mon-Khmer and Munda groups of languages whereas the Tibeto-Burman includes Burmese and various other languages of Burma.

An Austronesian ethnic group of around 2000 to 3000 people maintains a nomadic maritime community known as Moken Boat (Salone, Salung, Mawken, or Morgan). They speak different and unique Malayic or proto-Malay language compared with other Malayan languages. So, who are these Malays? The Malays are a people who had inhabited this island for a historically long period. They speak a language belonging to the Austronesian linguistic family called (Bahasa Melayu) Malay language. The generally accepted proposition is that most of the Malays came to Sri Lanka during the Dutch period, circa 17th century. One of the reasons for this assumption could be that the Dutch had kept records of their governmental operations.

Well, what if there was a relation between Austro-Asiatic people in the Mekong-delta and the Austronesian people that later formed Champa, explaining the rise of both kingdoms? As we now know that the Austronesians were master sea farers, they must have been largely responsible for the trade between India, South East Asian mainland and China. It is also far more likely that the Chams were the first to bring Indian culture to Funan, since there is no documentation of Indian Brahmins (documentation proved that Brahmins emigrated to other countries), but there is no mention of either Funan or Champa.

The Brahmins therefore were most likely Chams who were introduced to Indian culture directly by Indians through trade. This is evident in the earliest inscriptions of Funan, where titles were the same as in the Cham inscriptions. Table 1 below illustrated abudances of Malay classica texts used the term Tanah Melayu (The Malay Land) long before influenced by the Western (Fernandez, 1999). 
Table 1. The term Tanah Melayu (the Malay land) in indigenous classical texts (preindustrial eras)

\begin{tabular}{lll}
\hline Date/Period & Titles & Frequency \\
\hline 1603 & Tai al-Salatin (ed. Roorda \& ed. & 1 \\
$1625-1899$ & Warisan Warkah Melayu & 1 \\
$\sim 1700$ (MS 1849) & Hikayat Hang Tuah & 46 \\
$1796-1849$ & Surat Beriluminasi Raja Nusantara & 1 \\
1811 (MS 1811) & Hikayat Perintah Negeri Benggala & 3 \\
1838 & Pelayaran Abdullah ke Kelantan & 1 \\
1842, rev. 1849 & Hikayat Abdullah bin 'Abdul Kadir & 2 \\
1854 & Pelavaran Ahdullah ke Mekah & 1 \\
1855 (MS 189.) & Hikavat Siak & 2 \\
$<1859$ & Svair Kumhana Menaindera & 1 \\
1861 (MS 1878) & Carita Banaka & 3 \\
1865 & Salasilah Melavu dan Ruais & 2 \\
1866 (MS 1890) & Tuhfat al-Nafis & 1 \\
188.3 (MS 1883. 1932) & Hikavat. Pahana & 1 \\
1889 (MS 1889+) & Hadiqat al-Azhar wa'l-Riyahin & 1 \\
\hline
\end{tabular}

Source: Malay Concordance Project

(http://mcp.anu.edu.au/cgi-bin/tapis.pl) [Retrieved 8 April 2012]

But there are also reasons to believe a intermarry between the first kings of Funan and Austronesian as both Champa and Funan spread a similar origin story of foreigner coming from the sea marrying their local princess. The history also showed many examples of alliances between the royalties explained by blood relation. Based on the history, the Chams were not culturally dominant in the region, then, Khmer must be other strong community there and separate to Chams.

Vickery (2003) stated that available evidence of language of Funan was inconclusive but suggested the population to be Khmer. However, the exact ethnicity of the Funanese is still inconclusive due to lack of information but it is presumably towards the Funanese being a multiethnic society made up of Khmer Mon and other Austro-Asiatic peoples and maybe even Austronesians. One peculiar thing that differentiates Funan from following kingdoms like Chenla and Angkor was that it was a seafaring type empire rather than a land based one. Austro-asiatic peoples were never well known for their sea faring abilities. Or could Funan have been Austronesian and the predecessor of empires like Sri Vijaya? Or Champa? 
Ma Tin Cho Mar, Pham Huong Trang | ASEAN Journal of Community Engagement | Volume 4, Number 1, 2020

Speaking Austronesian is spoken in Brunei, Cambodia, Chile, China, Cook Islands, East Timor, Fiji, Polynesia, French Guam, Indonesia, Kiribati, Malaysia, Marshall Islands, Mayotte, Micronesia, Myanmar, Nauru, New Caledonia, Niue, the Philippines, Samoa, Tokelau, Tonga, Tuvalu, USA. The estimate is made of 311740.132 speakers per language with an average number of 3,384 referring to Wikipedia data. In the 17th century, when Polynesian words were compared to Malay words, the Austronean linguistic family was found to be present. Nevertheless, despite the greatest interest in science, the origin and history of the language family remained uncertain. Several experts suggested that they come from Taiwan (Formosa), while others assumed that they came from the Indonesian islands. Therefore, there are two branches of the Österreich language family: MalayoPolynesian, Formosan, which is sub-branched in Malaysia-Polynesian.

In addition, Professor Emeritus Tan Sri Pendeta Ismail Hussein stated in 2014 on the New Straits Times that building a nation needs to consider the concept of nationhood in both geographical and historical context. In this sense, it is important to state the fact that Malay-speaking world also includes communities in Thailand, Myanmar, Philippines and Sri Lanka.

\section{Conclusion}

On the search for regulations and fixed prototypes in human development, tracing the history is considered in the two important, interconnected fields of community engagement and development.

As a result, historical facts assist us, including the young, to encourage flexibility and a willingness to change our minds as we go to answering problems in all fields. And history helps us, particularly the young, to see the world in new ways. Learning about historical facts intended to gain a deeper understanding of our surroundings and our region and the historical forces that connect us, to continue our co-existence with each other and the environment.

When we talked about Malay World Civilization, there is no empty boast. Evidences such as Sunda Civilization circa 12-10,000 BC in Krakatoa islands site, between tip Java \& tip of Sumatra, even Mainland China were firstly explored \& settled by Mon Malays, cultivating rice, with fairly organized settlements i.e. Honan region about $3000 \mathrm{BC}$. The Chinese hordes, barbarians, came to overwhelm the Malays learning rice cultivation \& 
Ma Tin Cho Mar, Pham Huong Trang | ASEAN Journal of Community Engagement | Volume 4, Number 1, 2020

building houses \& settlements 1000 years later. Malay maritime was the earliest highest technological development the world over that led to global migrations to every corners of the earth. The earliest scientific age was in Sunda that spread out all round. Mountain terracing, scientific farming of rice, animal domestication, building of monuments, navigation, damming of rivers, taxonomizing \& naming plants/trees, naming of seas \& aquatic creatures were Malay contributions to civilization. This study attempted to reverse historical version that glorify olden days ASEAN civilization in these ASEAN need solely scientific researchers in all disciplines. The crucial objective is to look for groups of people who are relatively self-contained and self-sufficient, linked by social relationships with those that create viable collaborative activities such as making a living and fighting a war.

Finally, to our knowledge, these voices have remained silent until now. Indeed, life narratives under the ruling Burmese military dictatorship generally focus on ethnic minority members in conflict with the central Burmese authority, or the lives of antigovernment opponents. So, there are only a few life narratives of "ordinary" Burmese, specifically those who tried, less by confrontation than by life choices, and by taking advantage of opportunities to prosper economically and preserve a kind of freedom in a particularly challenging political and economic context. Thus, hope to bring a new understanding of the little-known region of southern Myanmar and the reactivity as well as adaptability of this Burmese society through the lives of these entrepreneurs.

\section{Author Contribution}

Ma Tin Cho Maret and Pham Huong Trang conceived of the presented idea. Ma Tin Cho Mar developed the theory and performed the computations. Pham Huong Trang verified the analytical methods. Ma Tin Cho Mar encouraged Pham Huong Trang to investigate the evidence bearing on the accuracy of historical data, the timeline, knowledge of the points of view or bias of documents and supervised the findings of this work. All authors discussed the results and contributed to the final manuscript.

\section{Acknowledgments}

This research was supported/partially supported by Dr. Wan Salleh Wan Ibrahim, Vice President, The World Melayu-Polynesia Organisation (WMPO). We are thankful for the 
Ma Tin Cho Mar, Pham Huong Trang | ASEAN Journal of Community Engagement | Volume 4, Number 1, 2020

experience and expertise of our colleagues and colleagues from the Malay Academy of Studies, University of Malaysia, who contributed greatly to the work but who may not support all the interpretations and conclusions in this paper. We want also to express our gratitude to all library media experts, who assisted our research in this way and helped us produce better results during data collection.

\section{References}

Andaya, B. W., \& Andaya, L. Y. (2016). A history of Malaysia: Macmillan International Higher Education.

Andaya, L. Y. (2002). Orang Asli and the Melayu in the History of the Malay Peninsula. Journal of the Malaysian Branch of the Royal Asiatic Society, 75(1 (282)), 23-48.

https://www.jstor.org/stable/41493461?seq=1\#metadata_info_tab_contents

Anderbeck, K. (2012). The Malayic-speaking; Orang Laut Dialects and directions for research. Wacana: Journal of the Humanities of Indonesia, 14(2), 265-312.

https://brill.com/view/journals/waca/14/2/article-p265_5.xml

Baker, C. (2014). A history of Thailand. United Kingdom: Cambridge University Press.

Baker, J. (2020). Crossroads: a popular history of Malaysia and Singapore. Singapore: Marshall Cavendish International Asia Pte Ltd.

Baldick, J. (2013). Ancient religions of the Austronesian world: from Australians to Taiwan. Tauris.

Belle, C. V. (2014). Tragic Orphans: Indians in Malaysia (Vol. 496). Singapore: Institute of Southeast Asian Studies.

Bernardini, W. (2005). Reconsidering spatial and temporal aspects of prehistoric cultural identity: A case study from the American Southwest. American Antiquity, 70(1), 31-54. https://www.jstor.org/stable/40035267

Boutry, M. (2014). The Maung Aye's Legacy. Burmese Lives: Ordinary Life Stories Under the Burmese Regime, 147.

Brown, K., \& Ogilvie, S. (2010). Concise encyclopedia of languages of the world. Amsterdam, The Netherlands: Elsevier.

Chambers, G. (2006). Polynesian genetics and Austronesian prehistory. Indonesian Institute of Sciences (LIPI). 
Ma Tin Cho Mar, Pham Huong Trang | ASEAN Journal of Community Engagement | Volume 4, Number 1, 2020

Chambers, G., \& Edinur, H. (2015). The Austronesian Diaspora: A Synthetic Total Evidence Model. 2(2), 53-65.

https://doi.org/10.15379/2410-2806.2015.02.02.06

Charney, M. (2009). A History of Modern Burma. United Kingdom: Cambridge University Press.

Din, M. A. O. (2011). Asal-Usul Orang Melayu: Menulis Semula Sejarahnya (The Malay Origin: Rewrite Its History). Jurnal Melayu, 7.

http://ejournal.ukm.my/jmelayu/article/view/5003

Embongak, A. M., Jusohb, J. S., Husseinc, J., \& Mohammadd, R. (2016). Tracing the Malays in the Malay land. Procedia-Social and Behavioral Sciences, 219, 235-240.

https://doi.org/10.1016/j.sbspro.2016.05.011

Fernandez, C. (1999). Colonial Knowledge, Invention and Reinvention of Malay Identity in Pre-Independence Malaya: A Retrospect. Akademika, 55(1).

http://ejournal.ukm.my/akademika/article/view/3012

Ghazali, A. Z., \& Ramli, Z. (Eds.). (2013). Panji pendeta: memperingati 50 tahun Professor Emeritus Dato'Dr. Nik Hassan Shuhaimi bin Nik Abdul Rahman dalam bidang pendidikan. Institut Alam dan Tamadun Melayu (ATMA), Universiti Kebangsaan Malaysia dan Ikatan Ahli Arkeologi Malaysia.

Harvey, G. E. (2000). History of Burma. New Delhi, India: Asian Educational Services.

Haspelmath, M., \& Tadmor, U. (2009). Loanwords in the world's languages: A comparative handbook.

Hinshiranan, N. (1997). The analysis of Moken opportunistic foragers' intragroup and intergroup relations.

Ibrahim, W. S. (2013). Reconstruction of Indo-Malayan archipelago's prehistory and the eventual peopling of Polynesia. Singapore: Institute of Southeast Asian Studies.

Ibrahim, W. S. (2017). Roots in Sanscritised Kambuja-desa: A Historical Reconstruction. Royal Academy of Cambodia, Phnom Penh.

Igboanusi, V. I. (2017). The Challenge of Cultural Identity on Regional Integration: A Case Study of ASEAN Community. SIAM University. https://e-research.siam.edu/wp-content/uploads/2019/05/MAPD-2017-IS-TheChallenge-of-Cultural-Identity-on-Regional-Integration-A-Case-Study-of-ASEANCommunity-compress.pdf 
Ma Tin Cho Mar, Pham Huong Trang | ASEAN Journal of Community Engagement | Volume 4, Number 1, 2020

Light, I., \& Gold, S. (2000). Ethnic economies. Academic Press.

https://ssrn.com/abstract=2761931

Lucassen, J., Lucassen, L., \& Manning, P. (2010). Migration history in world history: Multidisciplinary approaches: Brill.

Lynn, K. S. (2010). Burma (Myanmar). In E. C. F. Bird (Ed.), Encyclopedia of the World's Coastal Landforms (pp. 1081-1086). Dordrecht: Springer Netherlands.

na Thalang, C. (2017). Malaysia's role in two South-East Asian insurgencies:'an honest broker'? Australian Journal of International Affairs, 71(4), 389-404.

Norhalifah, K. N., Syaza, F. H., Chambers, G. K., \& Edinur, H. A. (2016). The Genetic History of Peninsular Malaysia. Gene, 586.

https://doi.org/10.1016/j.gene.2016.04.008

Omar, A. H. (1996). Languages and Language Situation of Southeast Asia. JATI-Journal of Southeast Asian Studies, 3, 14-27.

http://mojes.um.edu.my/index.php/jati/article/download/5614/3362

Renfrew, C. (1990). Archaeology and language: the puzzle of Indo-European origins. CUP Archive.

https://books.google.com.gi/books?id=R645AAAAIAAJ\&printsec=copyright\#v=onep age \&q\&f=false

Riccio, M. E., Nunes, J. M., Rahal, M., Kervaire, B., Tiercy, J.-M., \& Sanchez-Mazas, A. (2011). The Austroasiatic Munda population from India and its enigmatic origin: a HLA diversity study. Human biology, 83(3), 405-435.

https://doi.org/10.3378/027.083.0306

Simanjuntak, T., Pojoh, I. H. E., \& Hisyam, M. (2006). Austronesian diaspora and the ethnogeneses of people in Indonesian archipelago: proceedings of the international symposium. Yayasan Obor Indonesia.

Stier, T. (1927). With Pavlova round the world. United Kingdom: Hurst \& Blackett Limited.

Van Driem, G. (2007). Austroasiatic phylogeny and the Austroasiatic homeland in light of recent population genetic studies. Mon-Khmer Studies, 37, 1-14.

http://himalayanlanguages.org/files/driem/pdfs/2007MKS.pdf

Van Roy, E. (2018). Siamese Melting Pot: Flipside Digital Content Company Inc.

Vickery, M. (2003). Funan Reviewed: Deconstructing the Ancients. Bulletin de l'Ecole française d'Extrême-Orient, 90. 
Wan Teh, W. H. (2016). The Origins of Malay. Genetic Resources UITM press.

White, W. G. (1922). The sea gypsies of Malaya. New York, United States: Ams PressInc.

Wilkinson, R. J. (1923). A History of the Peninsular Malays with Chapters on Perak \& Selangor. Kelly \& Walsh.

http://myrepositori.pnm.gov.my/bitstream/123456789/4500/1/JB507KP_HPMC.p df. 